\title{
Defining human rights archives: introduction to the special double issue on archives and human rights
}

\author{
Michelle Caswell
}

Published online: 3 September 2014

(C) Springer Science+Business Media Dordrecht 2014

Is it possible the antonym of forgetting is not remembering but justice? Yosef Yerushalmi (2005, p. 117)

The majority of the papers in this special double issue on archives and human rights were originally presented at the symposium "The Antonym of Forgetting: Global Perspectives on Human Rights Archives," which was held October 18 and 19, 2013, at the University of California, Los Angeles. ${ }^{1}$ The symposium explored the complex political, ethical, legal, and cultural challenges faced in the creation, preservation, and use of records documenting human rights crises. In bringing together an international group of archivists and scholars whose work addresses archival issues in a broad range of countries - South Africa, Cambodia, East Timor, Indonesia, Bosnia, Croatia, Rwanda, and the United States-the symposium provided an opportunity to develop interdisciplinary scholarship at the intersection of archival theory and practice, human rights, history, anthropology, and law.

Interest in human rights within archival studies has exploded over the past decade. This burgeoning subfield has exposed the role of records, record creators,

\footnotetext{
1 The symposium was generously funded by a grant from the University of California Pacific Rim Research Program, with support from UCLA's Center for Information as Evidence, UCLA's Center for Southeast Asian Studies Indonesian Studies Program, UCLA's African Studies Center, and the Charles E. Young Research Library. Geoffrey Robinson served as PI for the Pacific Rim Research Program grant and co-organizer of the event and Kathy Carbone provided administrative expertise. The author would also like to acknowledge Marika Cifor for her administrative and editorial help with this special issue and Ricardo Punzalan for his suggestions regarding this introduction. More information about the symposium can be found at http://uclahumanrightsarchives.wordpress.com.
}

\section{Caswell $(\bowtie)$}

Department of Information Studies, Graduate School of Education and Information Studies, University of California, Los Angeles, 214 GSEIS Building, Box 951520, Los Angeles, CA 90095, USA

e-mail: caswell@gseis.ucla.edu

URL: http://www.michellecaswell.org 
archivists, and users in the committal and subsequent adjudication of, resistance to, or reconciliation for the most egregious human rights violations around the globe, including genocide, rape, mass incarceration, and other crimes against humanity (Ketelaar 2002; Harris 2007; Stinnett 2008; Levy and Sznaider 2010; McKemmish et al. 2011; Duff et al. 2013; Caswell 2014; Weld 2014). A complementary and similarly growing body of literature both within and outside archival studies looks at the function of records in less notorious but arguably just as damaging situations, including acts of marginalization, discrimination, starkly unequal resource distribution, and administrative violence that are endemic to contemporary societies worldwide (Spade 2011; Gupta 2012).

This special double issue of Archival Science contributes to and pushes the boundaries of these scholarly trends, investigating how societies use records, as well as archival institutions, programs, and functions, to come to terms with some of the most horrific abuses of the twentieth century. As many of the featured authors explore, the impact of these abuses - and their archival legacies-is ongoing. At the same time, this special double issue shifts the focus of the conversation about archives and human rights away from strictly legalistic frameworks based on the most nefarious cases and instead suggests we examine records that document discrepancies in and abuses of power everywhere as human rights archives. Despite the significance and unfortunate multitude of the extreme examples addressed in this issue-from records documenting genocide in East Timor to the impact of bureaucratic records on the lives of women in war-torn Bosnia-there are lessons to be learned from them that can impact how archivists in all settings work with and conceive of all sorts of seemingly quotidian records. Colonial encounters, the silencing of minorities, the sale and purchase of enslaved human beings, the epistemic violence of absence, misportrayal, and miscategorization-these are issues that are contained within and endemic to all archives everywhere. Documentation of power and its state-sanctioned abuse through violence are the common threads that bind human rights archives. With this expansive view in mind, this double issue posits that human rights archives are those collections of records that document violent and systematic abuse of power. However, in light of Eric Ketelaar's assertion that records must be "activated" to be meaningful, records documenting human rights abuse must be activated by individuals (including archivists), communities, and institutions in order to fulfill a human rights function (Ketelaar 2001, p. 138). The umbrella term "human rights archives" thus encompasses bureaucratic records that were created during the abuse itself; documentation created by human rights activists and lawyers after the fact for use in trials, tribunals, and truth commissions; stories recorded by survivors, victims' family members and communities to memorialize the dead and forge collective memory of past injustice; and, increasingly, forensic evidence such as DNA samples and satellite imagery that establish scientific facts about large-scale violence. All of these records are subject to and made meaningful through archival intervention via appraisal, selection, description, digitization, preservation, and outreach. Through this lens, "human rights archives" include not only those projects that self-identify as such (e.g., University of Texas at Austin's Human Rights Documentation Initiative, Duke University Libraries' Human Rights Archive), but also a wide array 
of collections documenting abuses of power kept by intergovernmental agencies, government and university repositories, nongovernmental and community-based organizations, families, and individuals alike. As Anne Gilliland asserted at the UCLA symposium, "All archives are human rights archives" (Gilliland 2013).

As many of the symposium participants noted, archivists and archival institutions can play a key role in helping societies deal with painful pasts and build peaceful futures through the creation, maintenance, and deployment of human rights archives. However, in order for archives to meet this role, they must actively forge a path ahead that leads to meaningful and contentious dialogue and debate, that promotes the rights of victims, that might favor forgetting and elision over memory and commemoration, and that helps societies acknowledge painful pasts and reconceptualize the future. How to do this is the central issue explored in the papers in this special double issue. The authors each examine a different dimension of archival work in relation to human rights abuses, ranging from the personal impact of post-conflict records, to the formation of communities around such records, to the role of nongovernmental, governmental, and international structures in creating such records and building archives to maintain them.

Verne Harris opens the special issue in his inimitably provocative style by problematizing simplistic equivocations of archives with justice or memory. Admitting that memory workers can be overwhelmed into paralysis by the enormity of injustice, Harris forges a path through the wilderness based around five overlapping lines of inquiry: community, truth commissions, healing, nostalgia, and haunting. By calling into question some of the field's basic assumptions about the positive implications of remembering, the necessity of overarching transitional justice frameworks, and the predetermined binary of victim and oppressor, Harris provides a much needed salvo to positivist constructions of archives. His contribution to this special issue is at once grand, with sweeping implications for the way we conceive of the impact of archival work, and intimately personal.

Honing in on the micro-level, Hariz Halilovich reveals the personal impact of the loss of records on Bosnian refugees living in a global diaspora. An anthropologist, Halilovich focuses the keen eyes of an ethnographer on the ways in which women are disproportionately impacted by recordkeeping regimes after conflict, uncovering how refugees (particularly women refugees) rebuild their lives through the recreation of missing or destroyed documentation. For Halilovich, such records are not only administrative and instrumental, but wholly personal, inextricably linked to the grieving process, and crucial for post-conflict identity formation, both in person and online. Anne Gilliland similarly employs ethnographic observation to examine the use of records in the aftermath of the Yugoslav wars. By collecting stories about how survivors of the war conceive of, access, and (in some cases) alter or fabricate passports and property records, Gilliland uncovers how individual experience can and should inform recordkeeping structures at the societal level. Here, she reveals the interplay (and most often) disconnect between the personal impact of recordkeeping on people's lives and national and international standards, arguing that an acknowledgment of the affective dimension of records and archives is key if archivists are to help communities impacted by violence "move forward," if not "move past." 
David Wallace, Patricia Pasick, Zoe Berman, and Ella Weber also analyze the personal impact of records documenting human rights abuse, focusing on the therapeutic powers of record creation in the aftermath of the Rwandan genocide. The result of an international collaboration between archivists and psychologists, Stories for Hope-Rwanda fosters intergenerational dialogues between youth and elders and archives audio recordings of such dialogue for future use. The team's article raises groundbreaking new possibilities regarding the healing powers of records creation and is the first to explore the psychological impact of archives documenting abuse from an interdisciplinary perspective.

Taken together, these four articles (by Harris, Halilovich, Gilliland, and Wallace et al.) represent an important shift toward the individual and the affective in archival discourse on human rights. This new trajectory in archival studies scholarship engages with critical work on affect theory in the humanities (Cvetkovich 2003; Ahmed 2004; Berlant 2011) and draws on work currently being done by emerging archival scholars at the intersection of archives and queer theory (Lee forthcoming; Cifor 2014). This affective turn opens up fruitful lines of inquiry that have the potential to transform current archival thinking in areas beyond the purview of human rights.

Zooming out from the impact of records on the individual to the group, my own contribution draws on insight gained from community archives discourses to inform archival practice regarding human rights records. Drawing on a wealth of literature on community archives (Flinn and Stevens 2009; Flinn et al. 2009; Bastian and Alexander 2009; Cook 2013), I posit that a community-centric approach to archives can be adapted in the human rights context to better meet the ongoing needs of survivors of human rights abuse and victims' family members. The proposed community-centric approach to human rights records is based on five principles learned from burgeoning community archives discourses: participation, shared stewardship, multiplicity, archival activism, and reflexivity. The paper examines how communities form around records documenting human rights abuse and argues that human rights records are community records first and foremost, regardless of the type of repository that stewards them.

Building on this community-centric approach to human rights documentation, historian Geoffrey Robinson explores how the records left behind by East Timor's truth commission are, like all archives, shaped by political and historical context. Robinson argues that rather than placing such records in the control of a central state-funded governmental repository, they are better left in the care of multiple, local, nongovernmental organizations. Drawing on work that calls into question accepted archival principles that are built on the assumption that records created by the state naturally belong in state archives (Caswell 2013), both Robinson and I shift our archival attention away from successor states to communities.

Least we mistakenly think human rights abuses are confined to the global South, Patricia Garcia and Jarrett Drake each provide examples of egregious abuse by governmental bodies in the USA. At the federal level, Garcia examines the ongoing detrimental impact of the H-2A visa program on migrant agricultural laborers. Expanding our conception of human rights archives beyond large-scale examples of war and genocide, Garcia unpacks the discourse surrounding the H-2A visa 
program, revealing how the government's classification of records enables abuses of power by employers. Garcia both highlights how federal law not only fails to protect vulnerable populations, but is complicit in their exploitation and demonstrates the ways in which records and recordkeeping practices are implicated in this failure. At the municipal level, Drake considers the implications of falsified testimony from New Orleans police officers in the aftermath of the Danziger Bridge shootings during Hurricane Katrina. Detailing how police relied on rhetorical tropes to fabricate records documenting their actions, Drake shows how archival evidence never exists in and of itself, but is always in the process of becoming. In highlighting just one example in which records were used to cover up excessive use of force by the state, Drake exposes how governmental records documenting abuse are social and political constructions and, in so doing, reminds us to problematize the relationship between records and "the truth."

At the intergovernmental level, legal scholar David Kaye examines the records left behind by the International Criminal Tribunal for the former Yugoslavia (ICTY), adding to a significant body of literature on the records of national tribunals and truth commissions (Peterson 2005, 2008; Harris 2007; Kenosi 2008), as well as those of intergovernmental bodies (Mnjama 2008; Adami 2009). Cautioning us against placing false hopes on the reconciliatory promise of archives, Kaye instead posits four key functions the ICTY archives might serve to document: the history of the abuses themselves, the process of adjudicating them, the act of international jurisprudence, and the administration of the ICTY as an institutional body of the United Nations. As Kaye's article shows, the path ahead may lay in tempering our lofty expectations of archives in the wake of human rights abuse.

Finally, Stacy Wood, Marika Cifor, Anne Gilliland, Kathy Carbone, and Ricardo Punzalan call on international bodies to reframe archival description in service of human rights activism. Interrogating standard archival concepts such as respect des fonds, original order, and provenance, the group proposes trust and transparency as guiding principles for describing sensitive records and building metadata models. By destabilizing some basic conceptual assumptions and their practical implications, their contribution furthers an ongoing dialogue in the field about the power of classification and the "liberatory" potential of archival description (Bowker and Star 1999; Duff and Harris 2002; Caswell 2012) and adds to recent work on the responsibilities archives have to Indigenous communities (Iacovino 2010; McKemmish et al. 2011; Janke and Iacovino 2012). This work challenges archivists to create practical solutions that ameliorate ongoing legacies of abuse.

With work ranging from the personal to the global, the authors of this special double issue incite us to assert human rights objectives as a crucial aspect of archival scholarship and practice. Despite their global range, the articles included here were not meant to be comprehensive; readers will find many silences here, including an absence of articles directly addressing Indigenous rights, LGBTQ issues, and the ongoing plight of Palestinians, to name just a few. The hope is that this special double issue sparks inquiry on such issues and others, reaching beyond simple solutions and inspiring future trajectories of scholarship and action within the field of archival studies and across disciplines. While the authors included here 
may leave many questions unanswered, they simultaneously suggest paths ahead (however circuitous) for the conceptualization and treatment of records documenting human rights abuse-great or small, widespread or isolated, historic or ongoing-everywhere.

\section{References}

Adami T (2009) Future perfect? Peacekeeping, peacebuilding and archives-the United Nations in Sudan. J Soc Archiv 30:3-26

Ahmed S (2004) Cultural politics of emotion. Routledge, New York

Bastian J, Alexander B (2009) Introduction: communities and archives-a symbiotic relationship. In: Bastian J, Alexander B (eds) Community archives: the shaping of memory. Facet, London

Berlant L (2011) Cruel optimism. Duke University Press, Durham

Bowker G, Star S (1999) Sorting things out: classification and its consequences. MIT Press, Cambridge Caswell M (2012) Using classification to convict the Khmer Rouge. J Doc 68(2):162-184

Caswell M (2013) Rethinking inalienability: trusting nongovernmental archives in transitional societies. Am Arch 76(1):113-134

Caswell M (2014) Archiving the unspeakable: silence, memory and the photographic record in Cambodia. University of Wisconsin Press, Madison

Cifor M (2014) Visceral forces: introducing affect studies to archival discourse. Archival Education and Research Institute, University of Pittsburgh, 14-18 July 2014

Cook T (2013) Evidence, memory, identity, and community; four shifting archival paradigms. Arch Sci 13(2-3):95-120

Cvetkovich A (2003) An archive of feeling: trauma, sexuality, and lesbian public cultures. Duke University Press, Durham

Duff W, Harris V (2002) Stories and names: archival description as narrating records and constructing meanings. Arch Sci 2:263-285

Duff W, Flinn A, Suurtamm KE, Wallace DA (2013) Social justice impact of archives: a preliminary investigation. Arch Sci 13:317-348

Flinn A, Stevens M (2009) 'It is nohmistri, wimekin history'. Telling our own story: independent and community archives in the UK, challenging and subverting the mainstream. In: Bastian J, Alexander B (eds) Community archives: the shaping of memory. Facet, London, pp 3-28

Flinn A, Stevens M, Shepherd E (2009) Whose memories, whose archives? Independent community archives, autonomy and the mainstream. Arch Sci 9:71-86

Gilliland A (2013) Moving past: probing the role of archivists and archives in the recovery and reconstruction of individual and community lives in Croatia. In: UCLA human rights archives symposium, Los Angeles

Gupta A (2012) Red tape: bureaucracy, structural violence, and poverty in India. Duke University Press, Durham

Harris V (2007) Archives and justice: a South African perspective. SAA, Chicago

Iacovino L (2010) Rethinking archival, ethical and legal frameworks for records of Indigenous Australian communities: a participant relationship model of rights and responsibilities. Arch Sci 10:353-372

Janke T, Iacovino L (2012) Keeping cultures alive: archives and indigenous cultural and intellectual property rights. Arch Sci 12(2):151-171

Kenosi L (2008) Records, national identity and post-apartheid South Africa: the role of truth commission records in nation building. Arch Manuscr 36(2):76-87

Ketelaar E (2001) Tacit narratives: the meaning of archives. Arch Sci 1(2):131-141

Ketelaar E (2002) Archival temples, archival prisons: modes of power and protection. Arch Sci 2:221-238

Lee JA (forthcoming) Beyond pillars of evidence: exploring the shaky ground of queer/ed archives and their methodologies. In: A Gilliland, AJ Lau, S McKemmish (eds) Research in the archival multiverse. Monash University Press, Melbourne

Levy D, Sznaider N (2010) Human rights and memory. Penn State University Press, University Park 
McKemmish S, Iacovino L, Ketelaar E, Castan M, Russell L (2011) Resetting relationships: archives and indigenous human rights in Australia. Arch Manuscr 39(1):107-144

Mnjama N (2008) The Orentlicher principles on the preservation and access to archives bearing witness to human rights violations. Inf Dev 24(3):213-225

Peterson TH (2005) Final acts: a guide to preserving the records of truth commissions. Johns Hopkins University Press, Baltimore

Peterson TH (2008) Temporary courts, permanent records. History and Public Policy Program, Woodrow Wilson Center for Scholars. http://www.wilsoncenter.org/sites/default/files/TCPR_Peterson_ HAPPOP02.pdf

Spade D (2011) Normal life: administrative violence, critical trans politics and the limits of the law. South End Press, Brooklyn

Stinnett G (2008) Archival landscape: archives and human rights. Prog Libr 32:10-20

Weld K (2014) Paper cadavers. Duke University Press, Durham

Yerushalmi Y (2005) Zakhor: Jewish history and Jewish memory. University of Washington Press, Seattle

Michelle Caswell is Assistant Professor of Archival Studies in the Department of Information Studies at UCLA. Her book Archiving the Unspeakable: Silence, Memory and the Photographic Record in Cambodia (University of Wisconsin Press, 2014) explores the role of archives and records in the construction of memory about the Khmer Rouge in Cambodia. Her articles on archives, social justice, and collective memory of trauma have appeared in Archival Science, Archivaria, American Archivist, Archives and Manuscripts, The Journal of Documentation, InterActions, First Monday and Libri. She is also the co-founder of the South Asian American Digital Archive (http://www.saadigitalarchive.org), an online repository that documents and provides access to the diverse stories of South Asian Americans. 